\title{
LINGUAGEM, TRADUÇÃO E SIGNO EM WALTER BENJAMIN
}

Deborah Spiga

\begin{abstract}
RESUMO
A intensão deste artigo é tematizar a particular tensão que liga origem e língua em Walter Benjamin. Analisando Sobre a linguagem em geral e sobre a linguagem do homem, evidenciei a anti-convencionalidade e a influência da tradição espiritual judaica na sua teoria da linguagem. Subsequentemente, no ensaio a Tarefa do tradutor mostrei como o tema da tradução está inextricavelmente ligado ao problema da origem como àquele entendimento tácito e "núcleo essencial" que subjaz a cada obra e fim messiânico de todas as línguas históricas. Em fim, apresentei o lado mimético da linguagem no texto Sobre a faculdade mimética, descrevendo não apenas como, para Benjamin, o homem é o maior criador de semelhanças, mas como isso ilustra a relação entre homem, mundo originário e língua pura. A partir dessa relação constitutiva feita de traços e signos, investiguei o papel do signo no pensamento benjaminiano, sua possível localização na tradição logo-fonocêntrica e sua relação com a pintura.
\end{abstract}

Palavras-chave: Língua. Tradução. Signo. Tempo. Origem.

\section{LANGUAGE, TRANSLATION AND SIGN IN WALTER BENJAMIN}

\begin{abstract}
The intent of this article is to address the particular tension that connects origin and language in Walter Benjamin. Analyzing On Language as Such and on the Language of Man, I revealed the unconventionality and the influence of the Jewish spiritual tradition of his theory of language. Subsequently, in the essay The task of the translator I showed how the subject of translation is inextricably linked to the problem of origin as that tacit understanding and "essential core" that underlies every work and messianic end of all historical languages. Finally, I presented the mimetic side of language in the author in the text About mimetic capacity, describing not only how, for Benjamin, man is the greatest creator of similarities, but how this illustrates the relationship between man, original world, and pure language. From this constitutive relationship made up of traits and signs, I investigated the role of the sign in Benjaminian thought and its possible location in the logo-phonocentric tradition and their relation with paint.
\end{abstract}

Key-words: Language. Translation. Sign. Time. Origin. 


\section{A língua como expressão e medium imediato}

A primeira obra em que nós focaremos é Sobre a linguagem em geral e sobre a linguagem do homem de Benjamin de 1916. Podemos perceber como já o titulo coloca o leitor na frente de uma primeira questão. De fato, porque diferenciar entre uma linguagem dos homens e uma não? Existe uma linguagem, assim como é comumente entendida, que não é falada por nós? Uma linguagem "geral" da qual a linguagem humana seria apenas um subconjunto? E se assim for, qual é o papel que o homem teria em tudo isso? Não é só a partir dele que pode começar qualquer investigação sobre a linguagem? Assim Benjamin introduz o tema:

Toda manifestação da vida espiritual pode ser considerada como uma espécie de linguagem [...] Não há evento ou coisa da natureza inanimada, que não participe, de alguma maneira, da linguagem, pois é essencial a tudo comunicar seu conteúdo espiritual. (BENJAMIN, 1982, 53. Tradução nossa).

Tudo tem uma própria "linguisticidade" intrínseca, nós conhecemos e entendemos somente porque algo nos é comunicado. Schweppenhäuser assim escreve a esse respeito: "A razão suficiente para conhecer algo em sua essência é cognibilitas, e essa é precisamente a implicação de sua fala; a causa do conhecimento é a verdadeira causa da linguagem. A linguagem como causa realis da causa cognoscendi é comunicatio" (SCHWEPPENHÄUSER, 1983, 53. Tradução nossa). Conhecemos enquanto comunicamos e comunicamos enquanto conhecemos. Cada coisa tem uma sua intrínseca "tradutibilidade" e isso quer dizer que nós compreendemos e conhecemos somente porque algo se nos comunica. É um relacionamento biunívoco o que liga conhecimento e linguagem. A linguagem é o médium de uma imediaticidade, um "entre" que nos permite a comunicação e a compreensão. Tudo o que nos rodeia, como criado, participa da linguagem. O ser linguístico, portanto, pertence como algo de essencial a tudo e não apenas a aquilo que normalmente consideramos dotado de palavra. De fato, por Benjamin, devemos entender como linguagem não somente música, escultura e desenho, que ainda representam manifestações 
espirituais do homem, mas cada coisa da natureza animada e inanimada. Esse "geral" da linguagem do título refere-se precisamente a isso; a uma investigação destinada a tudo aquilo que é uma expressão de um conteúdo espiritual. A linguagem, no entanto, não deve ser entendida como a comunicabilidade dos próprios objetos, mas somente do conteúdo espiritual. Com isto não se quer dizer nada de antropomórfico ou sustentar uma visão analógica em que o que não é humano para se tornar compreensível assume suas características linguísticas; mas de uma visão "inclusiva" da linguagem que mostra como tudo, "sem exceção", tem um conteúdo espiritual que comunica: "Toda comunicação de conteúdos espirituais é a linguagem, onde a comunicação através da palavra é apenas um caso particular, o da linguagem humana e do que está na base dela ou nela se baseia (jurisprudência, poesia)" (BENJAMIN, 1982, 53. Tradução nossa). Tudo tende a ser expresso. Tudo o que existe é expresso e tudo o que é expresso existe. Essa é a "bilateralidade ontológico-linguística" (SCHWEPPENHÄUSER, 1983, 53. Tradução nossa) da comunicação. Somente estendendo o horizonte linguístico também ao que normalmente é excluído, podemos recorrer a uma análise da linguagem livre de todas as restrições. Nesse sentido, refletir sobre a linguagem do homem significa questionar o problema da linguagem em geral. Isso ocorre porque: "o real, como criado, é uma realidade linguística e, portanto, participa da linguagem. Como existe, ele se expressa" (SCHWEPPENHÄUSER, 1983, 53. Tradução nossa).

Mas como se comunica tudo o que nos rodeia? Através da expressão (Ausdruck). Essa não é nada mais que a comunicação de um conteúdo espiritual que, enquanto comunicação, é necessariamente linguística:

Toda expressão, na medida em que se constitui como comunicação de conteúdos espirituais, é atribuída à linguagem. E não há dúvida de que a expressão só deve ser entendida, de acordo com sua inteira e mais íntima essência, como linguagem; por outro lado, para compreender uma essência linguística, é necessário sempre perguntar de que essência espiritual ela é manifestação imediata. (BENJAMIN, 1982, 52. Tradução nossa).

Se questionar sobre um ser linguístico significa perguntar-se de qual ser espiritual é expressão imediata, isso significa que próprio da língua é sua "imediaticidade". Mas esta não é, na verdade, o medium por excelência? Não é o "entre" que permite a comunicação e a compreensão? A linguagem é o meio Doutoranda em Filosofia pela Universidade Federal de São Paulo. Ítalo-brasileira, residente em São Paulo- SP. E-mail: deborahspiga@hotmail.it 
de um imediatismo. Esta é a expressão imediata de um conteúdo espiritual. Por outro lado, entretanto, isso não significa que a essência espiritual e a linguagem coincidem, mas apenas que a primeira "se comunica" na linguagem:

A essência espiritual comunica-se em uma língua e não através de uma língua, isto quer dizer que, vista do exterior, ela, a essência espiritual, não é idêntica à essência linguística. A essência espiritual só é idêntica à essência linguística na medida em que é comunicável. (BENJAMIN, 1982, 54. Tradução nossa).

O fato da essência espiritual não coincidir com a própria língua é o que torna de fato impossível qualquer identificação entre língua e significado. Com aquele "se comunica" é marcada uma diferença entre as duas. Elas são distintas, mas ligadas. Esse é o problema e a ambiguidade de toda teoria de linguagem. De fato, a distinção entre a essência espiritual de uma coisa e a língua na qual ela é comunicada é a diferença primordial de toda teoria da linguagem; a opinião para a qual, ao contrário, a essência espiritual e a língua coincidem é o grande abismo com o qual toda teoria da linguagem deve se confrontar. Mas o que levou a essa fusão e ao perigo do abismo? Benjamin encontra vestígios dessa ambiguidade no duplo significado atribuído à palavra logos, de modo que ela significa, ao mesmo tempo, "razão" e "linguagem". É precisamente a partir dessa relação peculiar que toda investigação da linguagem começa. Toda teoria de linguagem enfrenta esse problema: a linguagem é a essência espiritual de uma coisa ou não é? Por um lado, há a identificação entre linguagem e razão em detrimento de sua diferença; por outro lado, há a separação delas à custa de seu relacionamento intrínseco. A tensão entre as duas é o foco de toda pesquisa sobre a linguagem. A solução dessa ambiguidade, embora na forma de um paradoxo, constitui para Benjamin o coração da pesquisa e não o ponto de partida.

A pergunta que Benjamin agora se coloca é: o que a linguagem comunica? Assim, ele responde:

Comunica a essência espiritual que Ihe corresponde. É essencial saber que essa essência espiritual é comunicada na língua, e não através da língua. Portanto, não há um falante de línguas, se com isso queremos dizer aqueles que se comunicam através dessas línguas. O ser espiritual se comunica dentro e não através de uma língua - ou seja, não é externamente idêntico ao ser linguístico. O ser espiritual é identificado com o ser linguístico apenas na medida em que é comunicável. (BENJAMIN, 1982, 54. Tradução nossa).

Doutoranda em Filosofia pela Universidade Federal de São Paulo. Ítalo-brasileira, residente em São Paulo- SP. E-mail: deborahspiga@hotmail.it 
A diferença está aqui entre uma linguagem que expressa "através" dela a essência espiritual e uma linguagem que a expressa "diretamente" em si. No primeiro caso, estamos lidando com uma teoria da linguagem que vê nela como uma ferramenta que permanece externa tanto ao conteúdo quanto aos destinatários; no segundo, por outro lado, não existe exterioridade entre a essência espiritual e a linguagem, mas a linguagem constitui o meio no qual a essência espiritual se comunica. Mas se neste segundo caso é dada uma identificação completa entre um ser espiritual e um ser linguístico, isso não corre novamente o risco de uma identificação perigosa dos dois significados do logos? Não, porque aqui, em relação ao problema que foi colocado anteriormente, Benjamin acrescenta que essa identificação ocorre "apenas porque a essência espiritual é comunicável". Este é o paradoxo que permanece, ainda que não resolvido: a linguagem comunica a essência espiritual, mas esta última apenas enquanto comunicável. É nesse "enquanto" que está a diferença. Isso significa que a linguagem não pode ir além de si mesma e tentar comunicar o inexprimível, mas apenas problematizar seu limite. Repetimos: a essência espiritual é comunicada na língua, isso significa que aquilo que é comunicado é apenas sua comunicabilidade, que já é linguística. Assim Benjamin a este respeito:

\begin{abstract}
A resposta para a pergunta: $O$ que a linguagem comunica? é, portanto: toda língua comunica si mesma. A linguagem desta lâmpada, por exemplo, não comunica a lâmpada (já que a essência espiritual da lâmpada, como transmissível, não é de todo a lâmpada propriamente dita), mas a lâmpada da linguagem, a lâmpada-da-comunicação, a lâmpada-expressão. Porque isso acontece na língua: o ser linguístico das coisas é a sua língua". (BENJAMIN, 1982, 55. Tradução nossa).
\end{abstract}

A essência espiritual da lâmpada só pode ser a de que se fala, apenas sua "linguisticidade" e não a própria lâmpada. Dizer que a linguagem da lâmpada comunica a lâmpada da linguagem e, portanto, argumentar que "toda linguagem se comunica" parece, como o próprio Benjamin reconhece, levar a uma tautologia inevitável. Isso é resolvido, no entanto, se prestarmos atenção naquele "é" que identifica e, ao mesmo tempo, diferencia: "aquilo que em um ser espiritual é comunicável, é sua linguagem. Tudo depende desse é (o que significa "é imediatamente") [...] O que é comunicável em um ser espiritual é aquilo em que esta se comunica; isto é, toda língua se comunica" (BENJAMIN, 1982, 55. Tradução nossa). É desta forma que a natureza medial da língua 
expressa seu imediatismo. Isso é o que Benjamin chama de "mágica" da linguagem; o seu ser expressão imediata de uma medialidade e, ao mesmo tempo, medialidade de uma imediaticidade. Este é o paradoxo da linguagem em que estar suspensos. A linguagem como medium de si mesma não pode ser mediada, delimitada e circunscrita, mas subtrai-se a cada medida a ela exterior e, nesse sentido, é dotada de sua própria específica infinidade.

\section{A língua do homem, a revelação e o nome}

Dito isto, através de uma passagem da linguagem geral para a dos homens, Benjamin se pergunta: que coisa o homem comunica e de que forma? Para quem é direcionado isso? Assim, o filósofo responde:

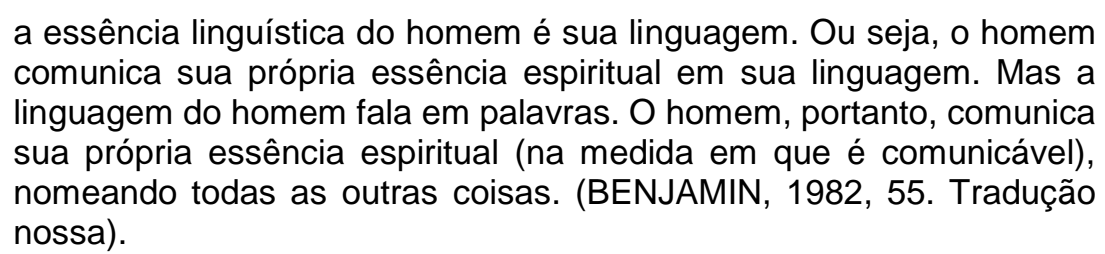

O homem comunica sua essência através da linguagem, através das palavras com que ele sonoriza as coisas. Mas como podemos definir a natureza nominativa do homem, ele se comunica na língua ou através dela? O homem, segundo Benjamin, comunica sua essência espiritual nomeando através das palavras; através dos nomes que ele dá às coisas, ele comunica sua essência linguística. Mas se assim for, poderíamos chegar novamente a conclusão que a linguagem humana é a única linguagem? A resposta é que, na verdade, esta não é a única, mas é a única "denominadora":

Conhecemos outras línguas que dão nomes às coisas? Não se opõe que não conheçamos outra língua além da do homem: o que não é verdade. Somente não conhecemos nenhuma linguagem denominadora além da do homem: identificar a linguagem denominadora com a linguagem em geral a teoria linguística priva-se das noções mais profundas. (BENJAMIN, 1982, 56. Tradução nossa).

Se a linguagem denominadora é própria do homem, essa referência às "noções mais profundas" refere-se, ao contrário, a uma linguagem que não pode ser reduzida ao horizonte estreito da linguagem da nomeação. A linguagem dos homens, na verdade, nada mais é do que um "derivado ectipo" Doutoranda em Filosofia pela Universidade Federal de São Paulo. Ítalo-brasileira, residente em São Paulo- SP. E-mail: deborahspiga@hotmail.it 
(SCHWEPPENHÄUSER, 1983, 56). Mas como se explica este linguagem e como os homens se comunicam? O homem se expressa na língua ou através dela? As que Benjamin apresenta aqui são duas concepções da linguagem apoiadas por duas facções diferentes. Por um lado, a concepção clássica e "burguesa" da linguagem, pela qual há uma mensagem que age como um instrumento entre um emissor e um destinatário e a palavra é entendida como referente a um objeto; por outro lado, existe a teoria da linguagem proposta por Benjamin que, com uma ruptura total da outra práxis canônica, não vê uma exterioridade entre as coisas e o homem, mas graças à linguagem uma comunhão. Ao nomear, de fato, o homem não apenas comunica sua essência espiritual, mas, ao fazê-lo, ele se comunica também com Deus. É o nome que aqui assume um papel fundamental. É neste que a essência muda da coisa é comunicada para Adão. Isso quer dizer que o nome expressa a comunicabilidade e a natureza linguística das coisas em geral, mas que neste não há derivação de significados porque nada é comunicado, exceto a própria linguagem. Se a língua é a expressão linguística da essência espiritual, na medida em que é comunicável; o nome se torna assim expressão da mediação imediata da linguagem. Este poder é dado ao senhor da natureza e é a ele que cabe a tarefa de nomear as coisas. De fato, é o primeiro homem, como imagem de Deus, que conhece as coisas em seu mais alto grau ${ }^{1}$ e é somente através dessa receptividade que ele pode nomeá-las. Ao fazê-lo, todavia, o homem não comunica a objetividade das coisas ou seu significado, mas a "língua pura":

\begin{abstract}
O nome é aquele através do qual nada é comunicado e em que a própria linguagem é absolutamente comunicada. No nome, a essência espiritual que é comunicada é a linguagem. [...] O nome como herança da linguagem humana, portanto, garante que a própria linguagem é a essência espiritual do homem; e somente por isso que a essência espiritual do homem, somente entre todos os seres espirituais, é inteiramente comunicável. É o que justifica a diferença entre a linguagem humana e a das coisas. Mas como a essência espiritual do homem é a própria linguagem, ele não pode se comunicar através dela, mas apenas nela. (BENJAMIN, 1982, 57. Tradução nossa).
\end{abstract}

\footnotetext{
${ }^{1}$ Interessante é apontar o que Franz Rosenzweig escreve na Estrela da redenção: "Os caminhos de Deus e os caminhos do homem são diferentes, mas a palavra de Deus e a palavra do homem são as mesmas". (ROSENZWEIG, 2008, 155. Tradução nossa).
}

Doutoranda em Filosofia pela Universidade Federal de São Paulo. Ítalo-brasileira, residente em São Paulo- SP. E-mail: deborahspiga@hotmail.it 
É somente nomeando o ser linguístico das coisas que o homem chega ao conhecimento. Isso significa que as criaturas mudas esperam ser nomeadas pelo homem. Somente assim a criação divina é concluída. Neste ponto, no entanto, parece ter uma reviravolta. De fato, se antes parecia que o homem com o nome se direcionava a Deus; agora, ao contrário, parece que é o próprio homem o destinatário da criação e que esta só pode ser concretizada graças à sua intervenção.

É esta a alma expressiva de toda a natureza, que é comunicada ao homem e no homem. Somente nomeando o ser linguístico das coisas o homem as conhece e é por isso que as criaturas silenciosas esperam que o homem as nomeie. Só assim a criação divina é completada: "A criação de Deus se completa quando as coisas recebem seu nome do homem" (BENJAMIN, 1982, 57. Tradução nossa). O que quebra essa circularidade é o poder do não expresso, do silencioso. Investigar esse mudo significa questionar-se mais uma vez sobre a identificação entre a essência linguística e a essência espiritual e abrir-se ao problema-chave da filosofia da linguagem: a revelação. Assim Benjamin escreve a este respeito:

Equação do ser espiritual com o ser linguístico é metafisicamente tão importante para a teoria da linguagem, porque leva a um conceito que surgiu de novo e de novo espontaneamente no centro da filosofia da linguagem e constituiu sua relação mais íntima com a filosofia da religião. E esse é o conceito de revelação. - Dentro de cada criação linguística, está em vigor o contraste entre o expresso e o expressivo com o inexprimível e o não expresso. $\mathrm{Na}$ análise desse contraste, vemos, na perspectiva do inexprimível, também o último ser espiritual. (BENJAMIN, 1982, 59. Tradução nossa).

Isso significa que a religião e a filosofia da linguagem podem ser encontradas no conceito de revelação precisamente porque se não existe o não dito na linguagem pura, também não há o não expresso na religião. Mas, o que é importante salientar aqui, é como na revelação não apenas se elude o perigo do não expresso chamando com o nome, mas como também nesta se revela 0 "ser espiritual supremo": Deus. Ele se revela ao homem exatamente enquanto nomeador. É nesta linguagem, a da revelação, que se revela a essência espiritual das coisas enquanto linguística e que as coisas mudas podem ser 
conhecidas e, portanto, nomeadas ${ }^{2}$. De fato, elas podem comunicar uma com a outra somente de acordo com uma linguagem exclusivamente material. É somente no acordo com a linguagem humana e na nomeação delas, que a comunicação eleva-se a um nível espiritual. Nesse sentido, a linguagem é revelação e conhecimento. Assim, Benjamin citando Hamann escreve: "A linguagem, a mãe da razão e da revelação, é A e $\Omega$ ” (BENJAMIN, 1982, 60. Tradução nossa). Razão e revelação: uma não deve ultrapassar a outra, mas é no hiato entre as duas que o poder da língua como razão pode ser limitado.

Mas chegados neste ponto, como Deus chama sua criação? A sua língua é sonora ou muda? Que tipo de relacionamento tem com a linguagem humana? É nesse ponto que Benjamin introduz a leitura de Gênesis. Aquilo que impressiona o filósofo alemão é o fato de que, na segunda versão da história da criação, o homem é o único não criado diretamente por Deus, mas pela terra. Se isso parece condenar o homem a uma espécie de inferioridade, em comparação com todas as outras criaturas; Deus, quase para compensá-lo por esta sua falta, confia-Ihe o dom da linguagem. Esta é a "revolução característica" (BENJAMIN, 1982, 60. Tradução nossa) na qual a criação se dirige ao homem para ser completada. Por um lado, o homem não é designado por Deus, mas por outro lado, através da linguagem, ele foi encarregado da tarefa de completar a criação na revelação. A segunda, no entanto, já está entendida e subjacente à primeira. Assim Rosenzweig, no livro Estrela da redenção, descreve essa relação que se abre para a redenção: "A revelação, precisamente porque se baseia na criação do conhecimento e na vontade é direcionada à redenção, é ao mesmo tempo uma revelação da criação e redenção" (ROSENZWEIG, 2008, 113. Tradução nossa).

Voltando á leitura de Gênesis é importante salientar como esta é descrita por Benjamin como um ato essencialmente linguístico. Seu ritmo é triplo e se a princípio a cadência com que ocorre é marcada pelo verbo, isto é, por um dizer

\footnotetext{
${ }^{2}$ Como esta relação se configure é eficazmente explicado por Rosenzweig: "a linguagem... se desperta para uma vitalidade real apenas na revelação. E, portanto, não há nada novo no milagre da revelação, não existe intervenção mágica sobre a criação já criada, mas é um signo, é um tornar visível e um devir explícito e sólido da providência oculta desde originada nas notas da criação, é totalmente revelação". (ROSENZWEIG, 2008, 113. Tradução nossa).
}

Doutoranda em Filosofia pela Universidade Federal de São Paulo. Ítalo-brasileira, residente em São Paulo- SP. E-mail: deborahspiga@hotmail.it 
que equivale a uma ação - "seja", "faça"; posteriormente, é apenas graças ao nome que Deus dá às coisas que a criação se concretiza. A onipotência criativa de Deus ocorre na linguagem, no verbo de onde a criação surge e no nome em que esta última é cumprida: "Em Deus, o nome é criador porque é um verbo, e o verbo de Deus é conhecido porque é nome" (BENJAMIN, 1999, 61. Tradução nossa). Graças a essa coincidência específica, as coisas são conhecidas apenas em Deus, como criadas; o homem, por outro lado, só pode se referir a esse nome divino como fundamento. Ele não conhece as coisas porque as cria e nomeia, mas apenas "na medida do conhecimento" (BENJAMIN, 1983, 62. Tradução nossa).

Vimos o ritmo em que se explica à criação da natureza. Agora, como acontece a criação do homem? É apenas a "trindade do ato" a ser mantida no triplo "criou" de Gn 1,27. Mas o que se destaca, segundo Benjamin, é como o homem não é nomeado por Deus. Isso, segundo nosso filósofo, é compreensível somente admitindo que Deus ao criar o homem:

\begin{abstract}
não queria sujeitá-lo à língua, mas no homem Deus permitiu que a linguagem saísse, o que o servira como meio de criação, livremente por si mesmo. Deus descansou quando confiou a si mesma, no homem, sua força criadora. Essa força, privada de sua realidade divina, tornou-se conhecimento. O homem conhece a mesma língua de que Deus é o criador (BENJAMIN, 1982, 63. Tradução nossa).
\end{abstract}

Deus não somente confiou seu poder criativo ao homem, mas também é somente através da "sonorização" da linguagem divina que o homem consegue completar a criação. O homem nomeia com sua linguagem sonora o nome das coisas. Isso significa, voltando ao exemplo da lâmpada, que ela não existe fora da língua, que só pode comunicar sua essência na medida em que expressa a língua. A lâmpada é o som da linguagem e é precisamente por esse motivo que ela também é um nome próprio. Essa conclusão leva Benjamin a desconfiar mais uma vez não somente da concepção burguesa da linguagem segundo a qual as palavras nada mais seriam do que rótulos, sinais convencionais das coisas, mas também da teoria mística da linguagem, segundo a qual a palavra é a essência das coisas. Mas, para Benjamin, é bom lembrar, a palavra é a essência da coisa apenas na medida em que é comunicável. Isso quer dizer que apesar da linguagem divina, a "língua pura" ser o verbo a ela falta o som; a linguagem 
humana, no entanto, embora não seja o verbo é o que completa a criação. Podemos portanto dizer que apesar da linguagem de Deus ser criadora e conhecedora, modelo "arquetípico", ela ainda requer a intervenção da linguagem humana. É a linguagem "fundadora", a linguagem das origens e perfeita em que o verbo e substantivo coincidem e, finalmente, língua original, "matriz" genealógica da não linguagem humana.

Nesse ponto, poderíamos nos perguntar, continuando a seguir Sobre a linguagem, qual é o ponto de contato entre a língua divina e a língua humana? O ponto onde elas se cruzam é o nome. Assim Benjamin escreve a este respeito:

O ponto em que a linguagem humana realiza a participação mais íntima no infinito simples do verbo, o ponto em que não é uma palavra acabada e não pode ter conhecimento - é o nome humano. A teoria do nome próprio é a teoria dos limites da linguagem finita comparada à infinita. De todos os seres, o homem é o único que nomeia sua própria espécie, assim como é o único que Deus não nomeou. (BENJAMIN, 1982, 62. Tradução nossa).

O nome próprio é o que melhor expressa a afinidade entre o verbo divino e a língua humana. O homem, embora não seja criado e nomeado na palavra, tem o poder de nomear; ele é o único, portanto, que nomeia o nome das coisas com as quais Deus as tornou conhecíveis. No entanto, o nome sobre o qual estamos falando aqui é o nome próprio e não o comum; no estranho sentido segundo o qual até os nomes das coisas se tornam nome próprios. Mas que coisa o nome próprio expressa e por que Benjamin vê neste um vínculo com a linguagem divina? O que caracteriza esse nome é que ele identifica sem designar. Como ele poderia, de fato, especificar se este é precisamente o que é justaposto antes do conhecimento? De fato, o nome próprio é aquele que recai sobre o nascituro e através do qual ele é conhecido e não vice-versa; somente a partir dessa imposição original o homem pode ser reconhecido. $O$ erro fundamental do homem é, segundo Benjamin, confundir o significado metafísico do nome com seu significado etimológico. De fato, no nome, o conhecimento é dado apenas de um ponto de vista etimológico, mas isso nunca pode corresponder ao homem e à sua verdade metafísica. O nome próprio, nesse sentido, não identifica nada e não é rastreável na malha do significado, mas é aquele som que, na mistura de verbo e nome, deu origem àquele ser através do qual o homem é conhecido como homem. O nome próprio através do qual o Doutoranda em Filosofia pela Universidade Federal de São Paulo. Ítalo-brasileira, residente em 
homem é chamado carrega os traços deste evento e é sua sonorização. É isso que Benjamin quer dizer quando afirma que "o nome é o destino do homem" (BENJAMIN, 1982, 63. Tradução nossa). Quando um homem é nomeado, ele está destinado a corresponder à essência que a linguagem nomeia.

Concluindo, se por um lado a nomeação do homem não é espontânea, mas receptiva, e é isso que lhe permite recorrer à criação e conhecê-la; por outro lado, a linguagem divina é criativa e espontânea, mas falha. Deus, de fato, depois de ter criado as coisas na palavra, sente a necessidade de conhecê-las em seu nome e é por isso que ele confia no homem. O nome é, nesse sentido, o único termo médio entre as duas línguas; o único que adere a ambas:

No nome a palavra de Deus não permaneceu criativa, tornou-se parcialmente receptiva, mesmo que linguisticamente receptiva. Essa recepção é dirigida à própria linguagem das coisas, a partir da qual se irradia sem som e na mágica silenciosa da natureza, a palavra divina. (BENJAMIN, 1982, 62. Tradução nossa)

Como chamar esse entrelaçamento entre a linguagem divina e a linguagem humana e como isso se refere a algo original e inefável, será o objeto do próximo parágrafo. Mas o problema que surge aqui é: como nomear algo que ficou mudo por sua "natureza" e que coisa pode fazer o filósofo depois da dispersão das línguas? De fato, a linguagem limita-se ao inexprimível que deve, no entanto, aparecer na palavra. Ele imitando o poder de Adão pode somente tentar recuperar a "percepção originária" da linguagem: "É tarefa do filósofo restaurar em sua primazia, através da representação, o caráter simbólico da palavra, com o qual a ideia se torna autotransparente, um acordo que é exatamente o oposto de qualquer comunicação externa" (BENJAMIN, 1999, 17. Tradução nossa). A tarefa do filósofo, portanto, é cavar e ir além do significado profano, da proliferação e da deriva de significados avulsos e apontar ao simbólico. A representação na linguagem, nesse sentido, não passa de uma tentativa de restaurar o lado simbólico da palavra. Ao escrever, o mutismo da natureza da ideia se transforma em palavras simbólicas que o filósofo deve tentar recuperar na percepção da linguagem. Própria do filósofo deve ser, deste modo, uma particular forma de recordar característico da anamnese platônica, que lhe permita recorrer à percepção original do ser linguístico da ideia. Os infinitos neologismos da filosofia contrastam com esta operação correta da filosofia como Doutoranda em Filosofia pela Universidade Federal de São Paulo. Ítalo-brasileira, residente em São Paulo- SP. E-mail: deborahspiga@hotmail.it 
recuperação do originário. Assim, Benjamin escreve: "Terminologias semelhantes - uma nomeação falhada, na qual a intenção participa mais do que a linguagem - permanecem estranhas à objetividade que a história atribuiu às principais elaborações da reflexão filosófica" (BENJAMIN, 1999, 18. Tradução nossa). Ao contrário, para Benjamin, o filósofo precisa de apenas algumas palavras e precisamente daquelas que, além da floresta da significação, restauram a palavra como nome, revelando a ideia.

\section{A tradução e a língua pura}

Deixamos o comentário do Gênesis, no ensaio Sobre a linguagem, no ponto em que a linguagem divina e a humana se encontram. Mas qual é o Mittelpunkt entre elas? A tradução. De fato, segundo Benjamin, esta não é uma transposição de um significado de uma língua para outra, mas aquilo que

adquire todo o seu significado ao entender que toda língua superior
(com exceção da palavra de Deus) pode ser considerada uma tradução
de todas as outras. Com a referida relação das línguas como meios de
diferentes espessuras, também é dada a traduzibilidade recíproca das
línguas. (BENJAMIN, 1982, 64. Tradução nossa).

O que faz isso acontecer, qual é a garantia desta tradução? A língua pura. Não apenas esta permite que a linguagem silenciosa das coisas se torne sonora, através da nomeação do homem; mas, ao mesmo tempo, cria uma lacuna, de modo que a linguagem do homem permaneça irredutivelmente inferior a ela. Como isso se configura? A língua pura é, ao mesmo tempo, modelo de traduzibilidade e o seu arresto. Traduzibilidade absoluta, mas também e, da mesma forma, exemplo de intraduzível. Problema de toda tradução é, segundo Benjamin, o medium. O que garante a objetividade da passagem de uma língua para outra, sua validade, especialmente se se trata aqui da passagem da linguagem silenciosa para a sonora? Quem permite este "transfert" é Deus, porque ele "criou as coisas, o verbo criativo nelas é o germe do nome que as conhece" (BENJAMIN, 1982, 64. Tradução nossa). Todavia, isso não é suficiente, porque isso não responde à tarefa do homem: nomear as coisas. $\mathrm{O}$ que torna isso possível é o fato que a linguagem das coisas e a linguagem do homem são "emparentadas" em Deus. Mas qual é o medium da língua muda e 
como essa afinidade mágica é percebida pelo homem? Seu meio é o signo. Assim Benjamin diz: "Deus dá aos animais um após o outro um signo de forma que eles se apresentem ao homem para serem nomeados. Assim, de maneira quase sublime, a comunidade linguística da criatura muda com Deus é expressa na imagem do signo" (BENJAMIN, 1982, 65. Tradução nossa). Como este não seja o signo tradicionalmente entendido como referência e reenvio e como o olhar do homem seja o maior produtor de semelhanças intangíveis, será o tópico do próximo parágrafo. Mas voltamos ao texto: do que depende a diferença hierárquica e axiológica entre a palavra muda e a aquela do homem, entre essa e a língua pura e entre as diferentes línguas? Isto é o resultado da expulsão do homem do paraíso terrestre. Assim Benjamin descreve esse momento:

O pecado original é a hora de nascimento da palavra humana, aquela palavra que abandonou a língua que nomeia, a língua que conhece, pode-se dizer: abandonou a sua própria magia imanente para reivindicar expressamente seu caráter mágico, de certo modo, a partir do exterior. A palavra deve comunicar alguma coisa (afora de si mesma). Esse é realmente o pecado original do espirito linguístico. (BENJAMIN, 1982, 65. Tradução nossa).

A palavra fundamental sobre a qual concentrar a atenção é precisamente aquele "exterior" ao qual se contrapõe o "enquanto tal" da essência espiritual e seu imediatismo como linguística. Se a magia da linguagem em geral era ser expressão imediata da própria medialidade, aqui ela se torna expressamente mágica, mas do lado de fora. Com o pecado original, com a escolha de Adão e Eva de comer o fruto do conhecimento, o nome se torna julgamento. O nome se torna em seu sentido mais vazio: "tagarelice"; a palavra deve expressar algo fora de si mesma. É a esta pobreza da linguagem que não expressa nenhum conhecimento que corresponde à tentativa de preenchimento da nominação, o relativismo linguístico e a necessidade interminável de tradução. A análise de Benjamin do pecado aqui reflete o pensamento de Kierkegaard. Todavia se, para ele, a escolha do bem e do mal é uma não escolha, escolha apenas como possibilidade de escolha; para Benjamin, o pecado é escolha de finitude e, ao mesmo tempo, escolha da sobrevivência histórica. É vertigem de liberdade. Em Benjamin, de fato, o homem é livre não apenas porque ele é o único não designado por Deus, mas também porque é a ele que a nomeação da criação é confiada. Falamos sobre o pecado, como uma reivindicação da palavra de 
conhecer o mal, mas o que isso comporta na linguagem? Principalmente três efeitos: em primeiro lugar, torna-se signo e, portanto, dispersão das línguas e traduzibilidade; em segundo lugar, torna-se mágica do julgamento e, por último, abstração. Por um lado, a abstração do mundo pós-celestial, por outro, a concretude e o imediatismo da linguagem antes da queda. Se a linguagem paradisíaca era "concreta" porque mantinha unida a tradução sonora das coisas, na medida em que denominava sua linguagem muda e levava a criação à conclusão; após a expulsão do paraíso, ao contrário, aquilo que permanece ao homem são somente "julgamento" e convenções arbitrárias. Se o homem antes do pecado designava a natureza e, desse modo, não apenas lhe dava voz, mas a conhecia em sua essência; depois da queda, a natureza torna-se silenciosa. Essa sua mudez, no entanto, é lamentação e melancolia, nostalgia por seu passado sonoro: "a incapacidade de falar é a grande dor da natureza (e resgatála é a vida e a linguagem do homem na natureza, e não apenas, como é suposto do poeta)" (BENJAMIN, 1982, 68. Tradução nossa). Cabe ao homem resgatar a natureza de seu silêncio. Mas, apesar das coisas serem nomeadas e sonorizadas através da linguagem paradisíaca do homem por que a natureza continua permanecendo triste? Essa tristeza alude ao que permanece não dito, àquele silêncio que permanece e que deixa um resto. Diante dessa situação, dada a mudez das coisas que rejeitam o homem, como ele pode realizar a criação e cumprir sua tarefa? Somente através de outras linguagens que respeitem esse mutismo, estas são "línguas das coisas", "línguas do material":

\footnotetext{
Há uma linguagem da escultura, da pintura, da poesia. Assim como a linguagem da poesia se funda - se não unicamente, pelo menos em parte - na linguagem de nomes do homem, pode-se muito bem pensar que a linguagem da escultura ou da pintura estejam fundadas em certas espécies de linguagens das coisas e que nelas, na pintura ou na escultura, ocorra uma tradução [...] da linguagem das coisas para uma linguagem infinitamente superior. Trata-se aqui de línguas sem nome, sem acústica, de línguas próprias do material. (BENJAMIN, 1982, 69. Tradução nossa).
}

Línguas em que a semelhança material predomina e não foi sufocada pela significação. São aquelas línguas em que a natureza se apresenta ao homem como signo, traço, exatamente como se apresentou ao homem do paraíso. Línguas que simbolicamente, através do signo, expressam o não comunicável. Esse não expresso e não comunicável que é o que torna afins as linguagens Doutoranda em Filosofia pela Universidade Federal de São Paulo. Ítalo-brasileira, residente em São Paulo- SP. E-mail: deborahspiga@hotmail.it 
históricas. Esse entendimento único que não é nada mais que fim messiânico das línguas e fim da significação.

Não expresso e fim da significação é o tema de outro importante texto juvenil de 1921, A tarefa do tradutor. Se na obra analisada anteriormente, a "língua pura" é origem das línguas históricas que permite não somente que a linguagem silenciosa das coisas se torne sonora, através da nomeação do homem, mas que cria também uma lacuna, de modo que a linguagem humana permaneça irredutivelmente inferior, aqui a "língua pura" é um parentesco que une todas as línguas pós-babélicas no desejo infatigável de sua restauração. Neste texto podemos ver como, em primeiro lugar, o filósofo desmascara a concepção vulgar, segundo a qual a tradução seria uma cópia do original útil ao leitor ou uma tentativa de recupero, mas como esta visa, na verdade, a essência da obra. O tradutor deve ser fiel ao original e ao mesmo tempo traí-lo, somente assim ele pode fazer a "língua pura" brilhar. A tradução é o que permite a "sobrevivência" das obras enquanto não somente estas possuem vida, mas também se desenvolvem e são históricas. A tradução assim não revela um significado oculto a ser trazido à luz, mas almeja seu "núcleo essencial" e isto

[...] pode ser definido como o que - em uma tradução - não é por sua vez traduzível. Em outras palavras, se remova tudo o que em uma tradução é comunicação e se traduza, permanecerá, ainda assim, intacto e intangível, aquilo para o qual o verdadeiro trabalho do tradutor visava. $E$ isso, por sua vez, não se deixa transferir como verbo poético do original, pois a relação do conteúdo com a língua é bastante diferente no original e na tradução. Se no primeiro eles formam certa unidade, como a fruta com a casca, a linguagem da tradução envolve seu conteúdo como uma capa real em dobras amplas. (BENJAMIN, 1982, 46. Tradução nossa).

O núcleo é o que resiste e orienta, ao mesmo tempo, a tradução. O problema que surge para o tradutor é precisamente este: como poder, com sua própria versão do original, visar à língua pura? Somente salientando como a vocação do tradutor deve expressar, através da tradução, justamente essa integração entre as línguas, essa afinidade, que não é semelhança, mas que é na verdade aquilo que as une, permanece não expresso na malha da tradução:

Essa relação íntima e oculta que podemos percepcionar entre as línguas constitui uma convergência e união muito particular que nos deixa ver que as línguas quanto às possíveis relações e parentescos 
históricos não são estranhas entre elas, mas a priori aparentadas e análogas naquilo que pretendem exprimir. (BENJAMIN, 1982, 42).

Aquilo que "aparenta" as línguas é o não expresso, o fim messiânico das línguas, o fim da significação. Língua pura que é expressão sem ser expressão, modelo e garantia de traduzibilidade. Aquele não expresso que subjaz a todas as linguagens históricas. $O$ arquétipo dessa tradução é, segundo Benjamin, 0 texto sagrado, modelo de traduzibilidade e intraduzibilidade ao mesmo tempo, porque é próprio neste que "o significado deixou de ser o confino entre o rio da linguagem e o da revelação" (BENJAMIN, 1982, 52. Tradução nossa). É expressão sem ser expressão, significação e intenção, modelo e garante da traduzibilidade. Mas o problema é: como pensar uma linguagem que não fala, que não comunica, que não significa? O seu dar-se em si é realmente impensável. Isto porque a linguagem pura, de fato, como salienta Moroncini "é dada apenas na tradução, no processo de tradução". (MORONCINI, 2009, 267. Tradução nossa). A tradução, neste sentido, é sempre processo e nunca conclusiva; somente aquela que traduzirá do signo para o símbolo e vice-versa coincidirá com o fim messiânico das línguas e a redenção. A possibilidade de uma história universal, neste sentido, está intrinsecamente ligada a isso; de fato, estas se tornam em Benjamin a mesma coisa. Uma tentativa, a este respeito, como relembra Benjamin, foi o esperanto. Mas este, enquanto tentativa de criar uma linguagem universalmente compreendida, leva novamente, segundo o filósofo, a um infinito querer dizer e a uma história universal na qual culmina outra vez o historicismo triunfante. O que Benjamin descreve, em vez disso, como "verdadeira" história universal depende e é co-implicado ao fim da confusão das línguas babélicas. Assim o filósofo alemão, naquele material preparatório que se tornarão as teses Sobre o conceito de história, escreve:

O mundo messiânico é o mundo da atualidade universal e integral. Somente nele é apresentada uma história universal. O que designamos hoje com esse nome sempre pode ser apenas uma espécie de esperanto. A esta [história universal] não pode corresponder nada, até que a confusão decorrente da torre de Babel seja reconstruída. Esta pressupõe a língua em que cada texto de um idioma morto ou vivo pode ser totalmente traduzido. Ou melhor, é essa mesma a própria linguagem. Mas não como uma [história] escrita, mas como uma [história] comemorada. Este banquete é purificado de todas as celebrações e não conhece canções de festas. Sua linguagem é a ideia da prosa em si, que é entendida por todos os homens, bem como pelos 
fortunados a linguagem dos pássaros. (BENJAMIN, 1997, 73. Tradução nossa).

A linguagem universal é aquela em que não há mais diferença entre dizer e entender, na qual a palavra não faz mais atrito, mas é prosa. Como Agamben diz a esse respeito:

\begin{abstract}
$\mathrm{Na}$ medida em que alcançou a perfeita transparência a si mesma, enquanto agora diz e pretende apenas si mesma, a palavra retornada à ideia desaparece imediatamente, é "pura história", mas uma história sem mais gramática, nem transmissão, que não conhece passado nem repetição, mas repousa unicamente em seu nunca ter sido. (AGAMBEN, 1983, 79. Tradução nossa).
\end{abstract}

Esta pura história que não é mais escrita, mas passado sem rastros, sombras e que nunca foi vivido. É somente assim que a originária cisão que dividia língua e história se reunirá em "um mundo da atualidade universal e integral”. Língua que perderá até seus traços e mergulhará em seu silêncio original para ser finalmente apenas prosa e língua celebrada.

Interessante é aqui salientar como é justamente o passado a verdadeira força motriz das teses Sobre o conceito de historia. O passado que não é algo concluído, algo de precluso para o qual podemos virar as costas imperturbáveis, mas que invade e quebra a quietude de um presente eternamente dilatado e voltado para o futuro. Um passado que não é acabado, mas que está sempre sujeito a uma nova reescrita e é revolucionário, pois permite a vingança em seu encontro com o presente de milhares de oprimidos. Um passado aberto que contrasta com a versão oficial, com a tradição do continuum, mas não de fácil leitura, implícito em sinais criptografados para descriptografar e sonhos para interpretar. Por outro lado, o futuro não é a parábola nem a miragem progressiva para a qual a humanidade tende, mas o abismo e a catástrofe em que a modernidade, cega pelo vislumbre do progresso, corre o risco de cair. O novo, na verdade, segundo Benjamin, pode ser tal somente enquanto atualização do pré-histórico. E o presente, como ele se configura na particular temporalidade benjaminiana? Não é a passagem eternamente dilatada do historicismo, mas é intrinsecamente intervalado de instantes revolucionários. Presente em que o passado que nunca existiu pode, em um determinado momento, brilhar no Doutoranda em Filosofia pela Universidade Federal de São Paulo. Ítalo-brasileira, residente em São Paulo- SP. E-mail: deborahspiga@hotmail.it 
"agora". Concretamente, isso significa assumir o controle do passado, "atualizando" o que nunca foi e que agora impele e pressiona com toda sua força. Somente nos votando ao passado e partindo de sua salvação que um futuro diferente pode aparecer. Somente através desse distanciamento particular podemos encontrar traços do que na história não teve voz ou foi silenciado e que agora rasga todo horizonte temporal. Os silenciados da história são os explorados, os marginalizados, os inomináveis, os párias de todos os tempos que, no "instante revolucionário", podem encontrar sua vingança. É somente com a "verdadeira imagem do passado" que o historiador materialista e o revolucionário podem bloquear o continuum histórico feito de escombros e opressão. Se o primeiro pode expulsar os vencedores da versão oficial da história, que anula toda injustiça e ignora a opressão dos oprimidos; o revolucionário no "momento de perigo" pode detonar o que de repente vem à luz e, assim, atualizar a origem no presente. É o sonho de um futuro melhor do que o próprio passado, um futuro como o destino ideal que corrompeu todos os impulsos revolucionários. Um futuro que, ao adiar a emancipação dos oprimidos, de fato permite não apenas a perpetuação da dominação incontestada da classe dos poderosos, mas também a extinção das faíscas de sua libertação. Mas assim, esta não apenas nunca chegará, mas as pessoas do passado e sua sede de vingança serão esquecidas e a libertação das cadeias da escravidão se tornará uma prerrogativa daqueles que virão e não dos perdedores do passado. Estes serão esquecidos e com eles a chance de sua salvação. De fato, somente através da lembrança de todas as vítimas do passado pode haver redenção. É a isso que a "frágil força messiânica" de cada um de nós se refere. Nossa tarefa é lembrar e, assim, fazer nossas as batalhas daqueles que nos precederam. Mas não como repetidores, mas como herdeiros ativos. A humanidade deve ser despertada do narcótico de seu presente e buscar no passado o que ainda está a ser realizado até que as coisas sejam reintegradas em seu estado originário. Nesse sentido, se, por um lado, a lembrança é o fio ao qual se apegar e, graças à qual se pode antecipar a vinda do Messias, da mesma maneira, a redenção não significa esperar, mas forçar e colher as gemas naquilo que agora começa a brotar. 


\section{Uma possível análise do signo como traço mimético e a sua leitura em um contexto logofonocêntrico}

A referência à rede "mágica" e "material" das coisas nos textos linguísticos antecipa os temas que serão abordados em um texto de Benjamin de 1933, Sobre a faculdade mimética. Aqui não apenas a natureza é representada como produtora de semelhanças, mas o homem é definido como o titular da maior capacidade de produzir semelhanças. A compreensão das semelhanças do homem, porém não é nada mais do que um enfraquecimento do seu lado mimético. E é justamente a partir dessa situação específica, de fato, que a linguagem aparece: "Temos um cânone que pode nos ajudar a esclarecer, pelo menos em parte, o conceito de semelhança imaterial. E esse cânone é a linguagem" (BENJAMIN, 1982, 72. Tradução nossa). A expressão, portanto, revela-se como faculdade eminentemente mimética. Este é o seu lado inconsciente, mágico como Benjamin diz. Nós nos encontramos mais uma vez diante do quiasma: linguagem-realidade das coisas. A faculdade mimética da linguagem, por outro lado, não se reproduz copiando um mundo já feito, mas processa-o através de gestos, sinais e traços; esta tem uma relação originária com o mundo. Nesse sentido, Moroncini:

Portanto, a primeira emergência de sentido não deve ser buscado na construção abstrata do conceito, mas na fisionomia da face, nos gestos do corpo, no desenho, em qualquer prática de inscrição os traços no qual se produza o esquema de uma coisa é produzido". (MORONCINI, 2009, 225. Tradução nossa).

É uma investigação filogenética da linguagem e da escrita que pode trazer à luz as correspondências entre mundo e homens. Quem possui essa faculdade, como já dissemos, é o homem. Essa sua capacidade, este "cânone" pelas semelhanças intangíveis é encontrada não apenas na linguagem, no comportamento imitativo da onomatopeia, mas, sobretudo na palavra escrita. Assim Benjamin diz a este respeito:

Onde é sintomático que esta [a palavra escrita] - em muitos casos, talvez, de maneira mais pragmática do que a palavra falada esclareça, com a relação de sua forma escrita com o significado do objeto, a natureza da semelhança imaterial. Em resumo, é a semelhança imaterial que fundamenta as tensões não apenas entre o 
dito e o entendido, mas também entre o escrito e o entendido e também entre o dito e o escrito. (BENJAMIN, 1962, 73. Tradução nossa).

Podemos ver aqui como Benjamin distingue claramente entre a palavra escrita e a dita. De fato, se a expressão é necessariamente linguística, isso não significa que esta é exclusivamente o "dito" da linguagem. De fato, esta pode ser também relacionada à linguagem muda das coisas, a saber, da escrita. Isso porque se no relacionamento entre a palavra e a coisa a faculdade mimética foi gradualmente perdida; é na escrita, ao contrário, que esta pode ainda ser encontrada. É na corporeidade da escrita enquanto signo, desenho, marca, gesto que podemos identificar sua semelhança imaterial e é próprio esta que cria a tensão "entre o dito e o escrito". Isso significa que a linguagem não é definida a partir do significado, mas que, ao contrario, é próprio a partir dessa faculdade mimética que são produzidas as semelhanças imateriais. A linguagem e a escrita, como miméticas, também se revelam em um "apoio" particular: o "elemento semiótico". Este é:

o portador no qual a semelhança acende rapidamente. Porque sua produção pelo homem - como a percepção que ele tem disso - é confiada, em muitos casos, e principalmente no mais importante, a um flash. Ele pisca de longe. Não é improvável que a velocidade da escrita e da leitura fortaleça a fusão entre semiótica e mimética na linguagem. (BENJAMIN, 1962, 73. Tradução nossa).

É neste momento mimético da linguagem que podemos entrever o rastro daqueles elementos mágicos próprios da época de sua formação nas comunidades pré-históricas. A língua neste sentido não se delineia como algo estranho e exterior para ser aprendido, mas como algo que constitui o homem e o forma na sua mais intima essência tornando-o histórico.

Vimos como a expressão é mimética e como esta correspondência pode ser lida mais na palavra escrita do que no fonema. Isso ocorre porque, se a palavra é a maneira de entender e comunicar alguma coisa, o signo é, mais propriamente, a maneira de representá-la. Partindo disso, a pergunta que agora podemos nos colocar é: existe uma reavaliação afirmativa da palavra escrita em Benjamin em relação à voz? Existe um desvio da tradição que Derrida chama de logofonocêntrismo ou não? Mas vamos por etapas e vejamos o que se entende com essa tradição e de onde ela vem. Podemos dizer, seguindo o filósofo francoDoutoranda em Filosofia pela Universidade Federal de São Paulo. Ítalo-brasileira, residente em São Paulo- SP. E-mail: deborahspiga@hotmail.it 
algeriano, que esta corresponde a toda a tradição filosófica ocidental. Tomando dois exemplos com os quais comparar Benjamin, poderíamos indicar: Platão e Husserl. É já no primeiro que podemos encontrar os traços daquilo que Derrida chama de "metafísica da presença". Desconfiança é por tudo o que é escrito: signo, sinal, entalhe, marca, inscrição. A escrita é morta posse. Segundo Platão, esta é cópia do original, filha bastarda que distorce a memória dos homens enganando-os. O sentido, ao contrário, é prerrogativa exclusiva da voz e não da materialidade da escrita; de fato, é justamente a respiração como "pneuma" que graças à sua imaterialidade consegue se aproximar melhor da intenção do significado. É a particular proximidade que une voz, consciência e presença, que poderíamos resumir banalmente na expressão "voz da consciência" que determina a supremacia da oralidade sobre a escrita.

Chegando mais perto de Benjamin, notória é a diferença feita por Husserl em suas Pesquisas lógicas entre o signo como índice (Anzeichen) e o signo como expressão (Ausdruck). Intenção de Husserl era salvar a pureza e a idealidade da expressão da voz viva da corporeidade e iterabilidade do signo como índice e marca. Era o índice como signo simples e morto, sem expressão e, portanto, sem significado a ser eliminado. Podemos notar, nesse ponto, como em Benjamin é precisamente o contrário, ou seja, como são precisamente os signos a serem determinantes no apoio à função expressiva e as suas correspondências imateriais. Para Husserl, por outro lado, tudo aquilo que é signo é exterioridade. $E$, para esse fim, ele procura um dispositivo linguístico que não se refira a nada além de si. O experimento levado ao extremo, nas Meditações Cartesianas, termina com a passagem do discurso oral - em que há ainda a intenção informativa própria da expressão e, portanto, mais uma vez 0 signo continua permanecendo entre os interlocutores - para a situação particular do monólogo interior. De fato, no discurso falado, permanece ainda, segundo Husserl, uma externalidade dada pelo fato de que sempre se volta para um interlocutor; é apenas na consciência que, ao contrário, o pensamento e o Erlebnis de cada um podem sentir-se sem nenhum intermediário, mas na mais completa aderência. No solilóquio, não apenas as palavras não informam mais e qualquer índice é excluído como referência e materialidade, mas a expressão 
torna-se presente no "tempo vivido" sem nenhuma referência. A expressão real está, portanto, em Husserl, numa voz sem som.

Agora voltamos a Benjamin e lembramos como ele define a linguagem como comunicação de um conteúdo espiritual em que a expressão da linguagem se comunica imediatamente. $O$ imediatismo da expressão carece completamente do adiamento do signo tão detestado por Husserl, o que resta aqui é apenas a diferença entre uma linguagem sonora e uma muda. O que para Husserl é a exterioridade do signo a ser eliminada a favor da pureza da expressão é precisamente o que Benjamin identifica com as semelhanças imateriais. Se Husserl, além disso, eliminou a corporeidade e a materialidade da voz, para Benjamin é graças a isso, através do som que o homem pode apostrofar as coisas do criado com seu nome. Se em Husserl o resultado de seu experimento foi um solipsismo extremo que reduziu o outro ao mesmo; em Benjamin, ao contrário, é uma questão de abrir para o outro, abrir para um relacionamento dialógico. Se, em conclusão, para o pai da fenomenologia, a voz silenciosa dividia o signo da expressão, e isso era definido apenas com base em seu significado; para o filósofo alemão, não apenas a expressão é um arquivo de semelhanças intangíveis, mas a voz também o é. De fato, esta reflete a natureza muda, mas ainda expressiva das coisas. Em última análise, a voz não é mais o que deve ser silenciado para manter sua idealidade, mas o que faz, mantendo traços "das semelhanças armazenadas no corpo; semelhança imaterial em si" (MORONCINI, 2009, 235. Tradução nossa).

Dito isto, Benjamin pode ser considerado um outsider da tradição filosófica ocidental logo-fonocêntrica ou podemos colocá-lo no seu grande grupo? Poderíamos responder que, se por um lado o papel da voz é inegável, como expressão imediata, como som e respiração que, ao nomear, comunica o conteúdo espiritual da criação e, portanto, a completa como revelação; por outro lado, no entanto, não há identificação entre voz e sentido. Em Benjamin, não há busca de uma idealidade de expressão que se separe do signo, precisamente porque este não é um reenvio, mas um traço no qual o homem pode ver o significado da natureza muda das coisas.

\section{Signo e a pintura}

Doutoranda em Filosofia pela Universidade Federal de São Paulo. Ítalo-brasileira, residente em São Paulo- SP. E-mail: deborahspiga@hotmail.it 
Até este ponto, lidamos com a relação dito-escrito, linguagem muda e linguagem escrita usando dois escritos: Sobre a linguagem em geral e sobre a linguagem do homem e Sobre a faculdade mimética; mas no que diz respeito ao signo, é na Pintura ou Zeichen e Mal de 1917 que podemos encontrar uma sua tematização mais explícita. Dada a afinidade dos temas desses textos, vamos analisá-los juntos, começando por este último.

O que leva Benjamin a comparar pintura e gráfica? Qual a diferença entre elas? Ou o que elas têm em comum? O que Benjamin pretende fazer não é uma investigação sobre o "sentido de leitura" de pinturas, mosaicos e arte gráfica, mas mostrar como estes, através de suas posições na frente do espectador, revelam importantes temas metafísicos. De fato, a necessidade de uma pintura ser mantida na posição vertical diante do espectador, que um mosaico fique ao pé horizontalmente ou que os desenhos das crianças não possam ser vistos na posição vertical "sem contradizer o sentido interno" não é um caso simples, mas corresponde, segundo Benjamin, ao que poderíamos chamar de um preciso estatuto ontológico interno. De fato, esse deslocamento se refere ao fato que:

a substância do mundo é atravessada por duas seções: a seção longitudinal da pintura e a seção transversal de certas formas de desenho. Parece que a seção longitudinal tem uma função representativa, contém coisas de alguma maneira; a seção transversal é simbólica: contém os sinais. Ou então somos os únicos a colocar a página na posição horizontal para ler; e há também uma posição vertical da escrita - a original, quando a escrita foi esculpida em pedra? (BENJAMIN, 1982, 202. Tradução nossa).

Por um lado, portanto, a seção longitudinal é representativa, por outro a seção transversal é simbólica. Se o lado explicativo é próprio da parte horizontal que revela as coisas que contém e representa; característica do transversal, ao contrário, é o seu ser codificado e simbólico. Dito isto, o fato que lemos um texto longitudinalmente é sintomático e revelador de algo ou é somente um dado convencional consolidado? E em que sentido, por exemplo, Benjamin colocaria a escrita chinesa, um tipo de escrita cuneiforme na qual o sentido de leitura era originalmente vertical e somente mais tarde foi modificado e girado horizontalmente? Esse tipo de escrita pictográfica que representava os seus significados verticalmente na folha seria colocado no conjunto de imagens ou no de signos? Na posição vertical do primeiro ou na horizontal do segundo? A 
condução desse tipo de investigação para Benjamin não comporta "simplesmente uma avaliação externa" (BENJAMIN, 1982, 202. Tradução nossa), mas essas afirmações determinam e revelam "relações metafísicas diferentes" (BENJAMIN, 1982, 202. Tradução nossa). Que a teoria dos signos une a filosofia da linguagem à arte, Benjamin o afirma expressamente:

é certo que a linguagem da arte só pode ser entendida em estreita conexão com a teoria dos signos. Sem o qual toda filosofia da linguagem permanece completamente fragmentária, uma vez que a relação entre linguagem e signo (da qual a relação entre linguagem humana e escrita é apenas um exemplo muito particular) é original e fundamental". (BENJAMIN, 1982, 69. Tradução nossa).

Isto precisamente porque o signo é um traço e não uma referência ou índice em que podemos traçar o aspecto simbólico da linguagem em "uma tradução da linguagem das coisas para uma linguagem infinitamente superior" (BENJAMIN, 1982, 69. Tradução nossa).

Mas é certamente em Pintura ou Zeichen e Mal que podemos ver como a relação linguagem-signo-arte é configurada. Aqui, o autor realiza uma pesquisa aprofundada sobre a diferença entre pintura e gráfica a partir da polaridade do significado de "Zeichen" e "Mal". Ambos em alemão significam signo. Além desse significado genérico, Benjamin encontra, no entanto, o que os une e ao mesmo tempo os separa em um "relacionamento metafísico". Em primeiro lugar, ao apresentar o Zeichen, ele afirma que "abrange vários campos, caracterizados pelos diferentes significados da linha. Esses significados são: a linha da geometria, a linha da letra alfabética, a linha gráfica, a linha do Zeichen absoluto (a linha mágica enquanto tal, não por causa do que representa)". (BENJAMIN, 1982, 204. Tradução nossa). A atenção de Benjamin é dedicada ao último dos significados do termo e podemos ver como nesse "enquanto tal" destacado e na linha mágica há uma clara referência ao lado mimético da linguagem. Mas é apenas no confronto entre Zeichen e Mal que o significado metafísico de ambos pode ser compreendido melhor. Se, para Benjamin, o primeiro tem um significado mais distinto de tipo espacial e interpessoal; o segundo, ao contrário, é mais temporal e relutante aos relacionamentos. Se exemplos de Zeichens absolutos são: 
o sinal de Caim, o sinal com o qual as casas dos israelitas foram distinguidas durante a décima praga do Egito, o sinal provavelmente análogo que aparece na história de Ali Baba e dos quarenta ladrões"; exemplos de Mal são o que aparece nos seres vivos (estigmas de Cristo, rubor, talvez lepra, desejos). (BENJAMIN, 1982, 205. Tradução nossa).

Se o primeiro estiver impresso, este dividiria entre um primeiro e um segundo plano como uma linha do horizonte - graças à qual poderíamos capturar a linha a partir do fundo e o fundo a partir da linha; o segundo, em vez disso, tem o caráter da mancha e emerge, vem à luz. Mas é quando Benjamin introduz o Mal na pintura que podemos vislumbrar como este delineia a intenção simbólica da linguagem. O Mal é descrito como o meio (Medium), mas, na verdade, é apenas com a entrada no campo da linguagem que a imagem pictórica pode ser nomeada. De fato, se

\begin{abstract}
a imagem fosse apenas Mal seria absolutamente impossível nomeá-la. No entanto, o verdadeiro problema da pintura é que, por um lado, a imagem é certamente $\mathrm{Mal}$ [...], mas, por outro lado, a imagem pictórica está relacionada a algo que ele próprio não é, ou seja, a algo que não é $M a l$, e isso exatamente enquanto é chamada. Essa relação com o que torna possível nomear a imagem pictórica, com o que transcende Mal, é o trabalho da composição. Este último representa a entrada no meio [Médio] do Mal de uma força superior, que insiste em sua neutralidade, ou seja, ocupa seu lugar no Mal sem forçá-lo ou quebrálo com a gráfica precisamente porque é infinitamente superior a esse Mal, mas não é hostil, mas semelhante. Essa força é a palavra da linguagem, que se enquadra no elemento da linguagem pictórica e é invisível como tal, mas é revelada apenas na composição. (BENJAMIN, 1982, 207. Tradução nossa).
\end{abstract}

Esta composição é o arranjo das cores na superfície da imagem que somente mais tarde se torna, através da entrada na imagem pictórica da língua, denominação. E isso porque, como já dissemos no início deste artigo, é impossível pensar em algo que não seja estruturalmente linguístico. É por esta razão que temos que pensar a imagem pictórica também como algo a ser nomeado. A entrada da língua no Mal se revela nada mais do que forma a pintura. Esta é a sua forma. Significativas, enfim, são outras "correspondências" de Benjamin entre linguagem e arte. Se, por um lado, as pinturas de Rafael são definidas como aquelas em que entrou sobretudo o Mal; o "nome", por outro lado, as pinturas contemporâneas são descritas como "palavras de julgamento". A concretude e a verdade do mundo celeste paradisíaco do primeiro por um lado, contra a abstração e a arte "conceitual" do mundo depois da queda no segundo. 
Esta é apenas uma das muitas "correspondências" do pensamento benjaminiano, à qual podemos acrescentar, no final deste artigo, talvez a mais pessoal: a correspondência entre escrita, o que se escreve e o que se é. Falei de correspondência não por acaso, porque Benjamin é talvez o filósofo do século $X X$, no qual biografia e escrita andam mais de mãos dadas. Onde podemos encontrar essas "semelhanças"? Poderíamos tentar vê-las em seu "estilo" filosófico, nas áreas de pesquisa selecionadas e nos termos utilizados. Como não ver também, em seus objetos de estudo, nas escolhas de autores marginais e não convencionais, uma escolha de campo? Como não entrever nas figuras usadas: cristal, mônada, mosaico, montagem a tensão especulativa particular de um filósofo e do seu trabalho assistemático? Seu período tem o fôlego de um fragmento, suas palavras são imagens, seu estilo é fisionômico. Sua paixão pela' escrita, finalmente, não é simplesmente mania grafológica tingida de esoterismo, mas a busca real de si mesmo naquilo que lhe era mais identitário e próximo.

\section{REFERÊNCIAS}

AGAMBEN, G. Lingua e storia. Categorie linguistiche e categorie storiche nel pensiero di Benjamin em Walter Benjamin. Tempo storia linguaggio. Roma: Editori Riuniti, 1983.

BENJAMIN, W. Angelus Novus. Saggi e frammenti, trad. it di R. Solmi. Torino: Einaudi, 1962.

BENJAMIN, W. Sul concetto di storia, trad. it di Bonola e Ranchetti. Torino: Einaudi, 1997.

BENJAMIN, W. Metafisica della gioventù, Scritti 1910-1918. Torino: Einaudi, 1982.

MORONCINI, B. Walter Benjamin e la moralità del moderno. Napoli: Cronopio, 2009.

SCHWEPPENHÄUSER, H. Nome/Logos/Espressione.Elementi della teoria benjaminiana della lingua em Walter Benjamin. Tempo storia linguaggio. Roma: Editori Riuniti, 1983.

ROSENZWEIG, F. La stella della redenzione. Milano: Vita e Pensiero, 2008. 
Doutoranda em Filosofia pela Universidade Federal de São Paulo. Ítalo-brasileira, residente em São Paulo- SP. E-mail: deborahspiga@hotmail.it 